30. Скупченко В.В. Внутрисосудистое лазерное облучение крови при различных заболеваниях нервной системы / В.В. Скупченко, Т.Т. Маховская, Г.Л. Хандурина // Низкоинтенсивное лазерное излучение в медицинской практике: Тез. докл. 4-й Дальневосточн. науч.-практ. конф. - Хабаровск, 1990. - С. 143-150.

31. Скупченко В.В. Лазерная терапия в неврологии / В.В. Скупченко, Т.Т. Маховская. - Самара-Хабаровск, 1993. - С. 80.

32. Кочетков А.В. Лазерная терапия в неврологии / А.В. Кочетков $_{2}$ С.В. Москвин, А.Н. Карнеев. - М., 2012. - 360 с.

33. Скупченко В.В. Лазеротерапия в коррекции репаративного морфогенеза / В.В. Скупченко, Е.С. Милюдин // Лазерная медицина. - 2009.- № 1.- С. 13-16.

34. Вплив низькоінтенсивного лазерного випромінювання на біологічні об'єкти та чутливість мікроорганізмів до антибактеріальних препаратів / В.В. Пантьо, В.І. Ніколайчук, В.І. Пантьо, А.В. Корунець // Фотобіологія і фротомедицина. - 2010. - № 1, 2. - С. 80-87.

\section{MODERN POSSIBILITIES OF LASER NEUROINFECTIONS}

\author{
L.V. Berezina
}

SUMMARY. The literature review is devoted to modern concepts of laser irradiation on the organism. Shows the current possibilities for the use of laser therapy in the neuroinfections.

Key words: infection, laser irradiation, neuroscience, laser therapy.

Отримано 26.05.2016 р.

\title{
КЛІНІКО-МОРФОЛОГІЧНІ ТА ФУНКЦІОНАЛЬНІ ЗМІНИ НИРОК У ВІЛ-ІНФІКОВАНИХ
}

\author{
ВДНЗУ «Буковинський державний медичний університет»
}

Встановлено, що вірус імунодефіциту людини (ВІЛ) вражає ниркову систему. Наведені дані, що високоактивна антиретровірусна терапія (ВАAPT) має негативний вплив на функціональний стан нирок. Також виявляються морфологічні та фрункціональні зміни у ВІЛ-інфрікованих. У літературних джерелах описані поодинокі дані про медикаментозну корекцію цих змін.

Ключові слова: ВІЛ-інфрекція, ВІЛ-асоційована нефрропатія, фокально-сегментарний гломерулосклероз, хронічна ниркова недостатність.

Останні дані ВООЗ свідчать про те, що розповсюдження ВІЛ-інфрекції серед населення земної кулі відбувається швидше, ніж передбачалося раніше, і на сьогодні воно вже набуває ознак широкомасштабної ендемії. Згідно з прогнозом, до 2020 р. від ВІЛ-інфекції на планеті може померти 16 млн людей. Кількість ВІЛінфікованих у Східній Європі та Центральній Азії сьогодні досягла 1,6 млн осіб, що у 10 разів перевищує показник попереднього десятиріччя, 75 \% інорікованих - люди віком до 30 років [1]. Як визначають епідеміологічні спо- стереження, особливості поширення ВІЛ значною мірою пов'язані з шляхами інфрікування. Так, найбільш стрімке і агресивне зростання темпів розвитку епідемічного процесу ВІЛ-інорекції спостерігається серед ін'єкційних наркоспоживачів. Статевий шлях інфрікування (як гетеросексуальні, так і гомосексуальні стосунки) визначає повільне, але більш масове охоплення населення. Тому особливості епідемічного процесу головно визначаються саме активністю того чи іншого механізму передачі збудника інорекції на конкретному етапі розвитку епідемії.

Україна займає одне з перших місць в Європі за темпами поширення ВІЛ-інфрекції. На 1 липня 2015 р. зареєстровано 271942 ВІЛ-інфрікованих. Під медичним наглядом перебуває 124279 ВІЛ-позитивних. Показник поширеності складав 291,3 на 100 тис. населення та був на 7,2 \% менший, ніж за відповідний період 2014 р. Серед шляхів передачі переважає статевий шлях і складає 59,2 \% проти 57,8 \% за 2014 р. Протягом січня-червня 2015 р. зареєстровано 3992 нових випадки, а за відповідний період 2014 р. - 5306. Відмічається зменшення числа нових випадків ВІЛ-інфекції на 24,7 \%. 
Рівень захворюваності зменшився на 25 \% порівняно 3 2014 р. Незважаючи на зменшення деяких статистичних показників, ВІЛ-інфекції приділяють багато уваги. У різних регіонах України інтенсивність епідемічних процесів виражена неоднаково. За показником загальної поширеності ВІЛ-інфекції та смертності від ВІЛ-інфекції західні області є відносно благополучні, але за темпом приросту захворюваності на ВІЛ-інфекцію вони посідають високі рангові місця, випереджаючи східні і південні області України. Така тенденція свідчить про активне залучення населення регіону до епідемічного процесу. Найвищі рівні поширеності ВІЛ-інфекції зареєстровані в Миколаївській та Київській областях (658,6 та 357,6 відповідно). Найбільша частка позитивних результатів припадала на осіб, які інфрікувалися статевим щляхом, ін'єкційних наркоманів, дітей, народжених від ВІЛпозитивних матерів, вагітних [2, 3]. ВІЛ-інфеекція характеризується повільним, але беззаперечним ураженням усіх систем, органів і людського організму в цілому та клітинного і гуморального імунітету зокрема [4].

Яким чином вірус знищує клітини-мішені, ще не зовсім ясно. Для пояснення цього процесу існують гіпотези вчених про різні механізми: накопичення РНК і ДНК у цитоплазмі та внутрішньоклітинне сполучення CD4+ 3 gр120. Інфіковані клітини можуть з'єднуватися 3 неінорікованими внаслідок взаємодії gр120 з CD4+, при цьому утворюються гігантські багатоядерні клітини. Зв'язуючись із поверхнею неінфрікованих Т-клітин CD4+, gр120 робить їх також чутливими до Т-лімфоцитів із специфічною клітиннотоксичною активністю. Білки ВІЛ здатні діяти як речовини-антигени, що призводить до виснаження популяції імунокомпетентних клітин. Внаслідок цього пригнічується здатність зазначених клітин виконувати специорічні захисні реакції в організмі хворого на ВІЛ-інфекцію. При цьому змінюється і якісний склад клітин, що представляють імунну систему. Дія збудника ВІЛ-інфекції проявляється на всіх стадіях, від проникнення до руйнування імунної системи та початку опортуністичних захворювань. Останні дістали таку назву тому, що вони спричиняються, як правило, непатогенними мікроорганізмами. Однак при недостатньому функціонуванні імунітету як системи захисту, мікроби використовують можливість (opportunity) прориву і здатність викликати захворювання [5-7].

Інтерес до проблеми ураження нирок при ВІЛінсрекції зростає в усьому світі. Це обумовлено тим, що ураження нирок, незалежно від стадії ВІЛ-інсрекції, характеризується прогресуючим перебігом з розвитком тяжких ускладнень. Тому необхідна рання діагностика патології нирок при ВІЛ-інфекції, яка, згідно з міжнародними рекомендаціями, повинна проводитися з моменту виявлення іноекції і базуватися на скринінгових дослідженнях маркерів ушкодження нирок - протеїнурії і зниженні швидкості клубочкової фрільтрації (ШКФ) [8]. ВІЛ-інфекція може спричиняти фокально-сегментарний гломерулосклероз, гострий дифузний проліферативний гломерулонефрит, мезангіопроліферативний гломерулонесрит (включаючи IgA-нефропатію), мезангіокапілярний гломерулонефрит і мембранозну нефропатію. Найбільш характерний фокально-сегментарний гломерулосклероз (ВІЛ-нефропатія), який може бути першим проявом ВІЛ-інсрекції. ВІЛ-несропатія (ВІЛ-АН) зустрічається у всіх групах ризику ВІЛ-інфекції, включаючи дітей, народжених від ВІЛ-інфікованих матерів, але найбільше вона поширена серед негрів та ін'єкційних наркоманів і у меншій мірі - серед гомосексуалістів. ВІЛ-нефрропатія проявляється тяжким нефротичним синдромом; термінальна ниркова недостатність розвивається через кілька тижнів або місяців $[9,10]$. Виживання на діалізі низьке, особливо у хворих з клінічними проявами термінальної стадії ВІЛ-інфекції. На даний час лікування не розроблено, проте $є$ окремі повідомлення про ефективність глюкокортикоїдів, інгібіторів АПФ і зидовудину, однак контрольних досліджень не проводилося [11].

Низка морфологічних ознак дозволяє відрізнити ВІЛ-нефропатію від первинного фрокально-сегментарного гломерулосклерозу. Світлова мікроскопія виявляє спадання петель клубочка, виражене тубулоінтерстиціальне запалення і мікроцисти, що утворилися 3 розширених канальців. При електронній мікроскопії в ендотелії клубочків, епітелії канальців і лейкоцитах запального інфільтрату виявляють характерні включення, що містять мережу з розгалужених трубочок $[11,12]$. Механізм розвитку ВІЛ-нефропатії точно невідомий. У нирках хворих виявлена вірусна ДНК, проте її знаходять і у ВІЛ-інфрікованих без нефропатії. Ймовірно, для розвитку нефропатії необхідні якісь додаткові фактори. Раніше вважали, що вживання наркотичних речовин, особливо героїну, зафріксоване у 30-60 \% ВІЛ-позитивних пацієнтів, $€$ фрактором ризику ВІЛ-АН. Крім того, у групі пацієнтів 3 ВІЛ-АН фракторами передачі ВІЛ-інфекції були не тільки внутрішньовенне вживання психотропних препаратів, а й гомосексуальні, бісексуальні й гетеросексуальні контакти. Це свідчить про те, що ін'єкційний шлях зараження сам по собі не є фактором ризику розвитку ВІЛ-АН $[8,13]$.

На даний час до фракторів ризику розвитку ВІЛАН відносять: приналежність до негроїдної раси та високу концентрацію РНК ВІЛ (>100000 копій/мл), значно переважають особи чоловічої статі, наявність захворювань нирок у найближчих родичів. Класичний варіант ВІЛ-АН характеризується порушенням функції нирок, швидким прогресуванням захворювання 
протягом 1-4 міс., клініко-лабораторно проявляється протеїнурією, відсутністю набряків, гіпоальбумінемією та змінами в сечовому осаді. При УзД виявляють підвищену ехогенність паренхіми нирок. В осіб з більш низьким імунним статусом (рівень CD4+<200 кл./мм³) захворювання може перебігати у тяжчій фрормі [11, 12, 14]. За результатами одного дослідження був зроблений висновок про те, що ВААРТ запобігає розвитку ВІЛ-АН, оскільки на їі тлі спостерігалося зниження захворюваності на 60 \%. Однак за результатами дослідження, що включав 61 випадок, було встановлено, що успішне зниження реплікації вірусу на тлі ВААРТ сприяє збільшенню тривалості життя, але не впливає на прогресування захворювання нирок $[8,15]$.

Відзначено, що порушення фрункцій нирок швидше за все призводить до ВІЛ-АН [16]. У 82 \% діагностовано пієлонефрит, який згодом прогресував і призводив до розвитку ВІЛ-АН. Також було відмічено, що ступінь порушення фрункції нирок немає чіткої межі, тобто немає клінічних проявів, а зміни діагностуються тільки лабораторно.

При автопсичному дослідженні хворих на ВІЛінфрекцію із супутнім пієлонефритом були виявлені структурні зміни коркової та мозкової речовини, поява колоїдних включень, зміна ендотеліоцитів. У ниркових канальцях виявляли набухання мембран саме канальців, збільшення коркової речовини відбувалося за рахунок колоїдних включень і волокнистих структур. Тому у роботі [16] зроблено висновок, що ВІЛ-АН має стертий характер, з ураженням епітелію проксимальних канальців, але без лімфоцитарної інфільтрації коркової речовини нирки. Частота і тривалість захворювання призводить до розвитку хронічної ниркової недостатності (XНH) [16]. За результатами досліджень, проведених у різних країнах, частота ХНH у ВІЛінфікованих пацієнтів варіює від 5 до 33 \%. Відмінності в епідеміології ХНН пов'язані з критерієм встановлення діагнозу, з расовим складом популяції, коморбідними захворюваннями, імунологічними та вірусологічними показниками пацієнтів у групі, що досліджувалася. Слід відзначити переважно безсимптомний перебіг захворювань нирок, так як навіть при зниженні ШКФ і розвитку азотемії близько 50 \% хворих не пред'являють ниркових скарг. Виходячи з відомого визначення ХНH, можемо зробити висновок про фрормування ХНH у більшості хворих на ВІЛ-інфекцію. При цьому, чим довше хворіють пацієнти, тим вище відзначається рівень креатиніну крові, нижче ШКФ і, як наслідок, швидше розвивається ниркова недостатність. Збільшення тривалості життя ВІЛ-інфрікованих пацієнтів на тлі застосування ВААРТ призводить до зростання частки вторинних уражень нирок, обумовлених водно-електролітними, гемодинамічними порушеннями, нефротоксичною дією лікарських препаратів, цукровим діабетом і артеріальною гіпертензією, а також інфрекційними та онкологічними ускладненнями $[17,18]$.

Вплив препарату теновіру, що широко застосовують у ВААРТ як препарат першої лінії, дослідила і О.В. Рябоконь [13]. Теновір є одним із нуклеотидних інгібіторів зворотної транскриптази і є досить ефрективним у схемі лікування ВААРТ, проте після його прийому протягом 1-2 міс. відмічається зменшення ШКФ, набряки, гіпертензія, біль в попереку та суглобах [19]. У своєму дослідженні О.В. Рябоконь дійшла висновку, що ураження ниркової системи при прийомі теновіру виникає тільки в термінальній стадії ВІЛ-інфекції, зазвичай спостерігається у чоловіків [13].

Важливим фрактором $€$ наявність опортуністичних інфрекцій та кількість CD4-лімфоцитів менше 200 в 1 мкл. Серед опортуністичних інфекцій переважають туберкульоз та пневмоцистна пневмонія [11, 13, 20, 21]. У США тенофровір $є$ ефективним і широко використовується для лікування ВІЛ-інфекції і вірусних гепатитів. Дослідження показують, що тенофровір має низький загальний профріль токсичності, але впливає на розрахунок ШКФ і призводить до диссрункції ниркових канальців, а у тяжких випадках розвивається ниркова недостатність та синдром Фанконі [20-22].

ВІЛ-асоційована тромботична мікроангіопатія (ВІЛTMA) також розвивається під прямим впливом вірусу, цитокінів або дією протеїнів. ВІЛ-ТМА з'являється в будь-якій стадії ВІЛ-інфекції. Характерними рисами ВІЛ-ТМА $є$ відмінності в частоті тромбоцитопенії у серопозитивних осіб (3-5 \%) і у пацієнтів з термінальною стадією ВІЛ-інфрекції (30-45 \%). ВІЛ-ТМА призводить до розвитку незворотної втрати ниркової функції з летальним завершенням, на тлі поліорганної недостатності $[8,11]$. ВІЛ-ТМА виникає на фроні дисфункції ендотеліальних клітин, а також зниження вмісту фрактора фоон Віллебранда, що розщеплює протеазу. Клінічно для ВІЛ-ТМА характерно 5 основних симптомів: лихоманка, неврологічні дисфункції, тромбоцитопенія, мікроангіопатична гемолітична анемія і гематурія. Високий рівень протеїнурії є однією з основних диференційних ознак, яка допомагає встановити діагноз ВІЛ-ТМА [12, 22-24].

Утворення антитіл до білків ВІЛ супроводжується фрормуванням у нирках імунних комплексів з розвитком імунокомплексних гломерулонефритів (ІКГН). В європеоїдній і іспаномовній ВІЛ-інфікованих популяціях, на відміну від негроїдної раси, найбільш поширені ІКГН, зокрема, IgА нефропатія, і рідше фокально-сегментарний гломерулосклероз (ФСГС) [10]. При дослідженні авто- 
псичного матеріалу хворих на ВІЛ-інфекцію із супутнім ураженням ниркової системи ІКГН зустрічається в межах 25 \%. Число можливих фракторів ризику ураження нирок при ВІЛ-інсрекції продовжує постійно збільшуватися, однак реальне їх значення не завжди вдається довести. Часто зустрічається коінфекція вірусами гепатитів В і C, що може спричиняти розвиток мембранозної нефропатії, мембранопроліферативного і кріоглобулінемічного гломерулонефриту (ГН), васкуліту. Зростання частки вторинних уражень нирок обумовлено психотропними та наркотичними засобами, інфекційними та онкологічними ускладненнями в термінальній стадії захворювання, широким застосуванням потенційно нефротоксичних антибактерійних, противірусних, протигрибкових, нестероїдних протизапальних препаратів, 3 подальшим розвитком гіпертензивного нефроангіосклерозу, діабетичної гломерулопатії, гострого або хронічного тубулоінтерстиціального нефриту (TIH) [9-12, 23]. IgA несропатія виникає у ВІЛ-інфікованих пацієнтів та ії частота ще досі не вивчена. При автопсичному дослідженні нирок ВІЛ-інфікованих людей IgA нефропатія виявляється у 8 \%. Всі випадки цього ускладнення бувають винятково у чоловіків європейського походження. ВІЛ-асоційована нефропатія IgA, як правило, характеризується протеїнурією, гематурією, а згодом призводить до початкової стадії ниркової недостатністю $[11,12,23]$. Традиційно для оцінки фрункції нирок використовують ШКФ, яку розраховують на основі ендогенного креатиніну по формулам Cockcroft-Gault або Modification of Diet in Renal Disease (MDRD) [25]. У дослідженні [26] встановлено, що у ВІЛінсікованих хворих рівень сироваткового креатиніну був значно нижче, ніж у хворих без ВІЛ-інфекції. У той же час науковці не виявили відмінностей у величині креатиніну крові ВІЛ-серопозитивних і ВІЛ-серонегативних хворих. Вищу поширеність зниження ШКФ менше 60 мл/хв (7,4 проти 2,1 \%) і, відповідно, підвищені значення креатиніну крові (1,13 проти 0,95 млмоль/л) при ВІЛ-інфекції порівняно з ВІЛ-негативними особами виявили Е.T. Overton та ін. (2009) [25-27].

Цистатин С - неглікозильований білок з молекулярною масою 13,4 кДа, який належить до родини інгібіторів цистеїнових протеїназ. Цей білок з постійною швидкістю синтезується всіма ядерними клітинами організму, вільно фрільтрується через клубочкову мембрану і повністю метаболізується в нирках. У нормі цистатин С не секретується проксимальними нирковими канальцями [25]. У пацієнтів з ВІЛ-інфрекцією реплікація вірусу імунодесріциту може бути одним 3 фракторів, який впливає на концентрацію цистатина С у крові. Іншими потенційними фракторами можуть служити кількість CD4+-клітин і зменшення синтезу цистатина з макрофрагами. У ряді досліджень було показано, що низький рівень CD4+-лімфроцитів асоціюється 3 підвищеною концентрацією сироваткового цистатина С. При цьому також фракторами ризику більш високих значень цистатина з'явилися підвищена концентрація сечової кислоти в крові, протеїнурія, наявність гіпертензії, коінфекції з гепатитом С, тривале лікування антиретровірусними препаратами. На противагу цьому, в роботах J. Jaroszewicz та ін. (2006) і C. I. Esezobor та ін. (2010) кореляції між кількістю CD4+-лімфоцитів і рівнем сироваткового цистатина С не було виявлено [25-29]. Переваги цистатина С перед креатиніном в оцінці функції нирок при ВІЛ-інфекції було показано A. Bonjoch та ін. (2010) [29]. За їхніми даними, рівень сироваткового цистатина С більшою мірою корелював 3 ШКФ, за допомогою радіоізотопних методів, ніж з ШКФ, розрахованої за формулами Cockcroft-Gault, MDRD i CKD-EPI. Тому вчені рекомендують поєднувати дослідження креатиніну та цистатину С для максимально правильного визначення ШКФ. В.Н. Бондаренко у своїх роботах дійшла висновку, що визначення цистатина С більш точно відображає фрункцію нирок, особливо на початкових стадіях зниження ШКФ. Також встановлено, що при ВІЛ-інфекції ШКФ пов'язана із загальною летальністю тільки при їі розрахунку за цистатином, а не тільки за креатиніном [25].

\section{Висновки}

1. При ВІЛ-інфекції ураження ниркової системи спостерігається у 80 \% хворих на цю недугу. Тому необхідна своєчасна діагностика специфічних маркерів, а саме альбумінурії, ШКФ, протеїнурії.

2. Хронічна хвороба нирок у ВІЛ-інсрікованих пацієнтів представлена двома клінічними варіантами - тубулоінтерстиціальними і гломерулярними ураженнями. Морфологічна структура гломерулярних захворювань нирок характеризується фокально-сегментарним гломерулонефритом та імунно-комплексним гломерулонефритом. Хронічна ниркова недостатність може розвиватися на будь-якій стадії ВІЛ-інфекції. Виразність протеїнурії і тяжкість порушення фрункції нирок не залежать від статі, віку, шляхів інфікування та тривалості ВІЛ-інфекції.

3. Ураження нирок у ВІЛ-інфрікованих пацієнтів розвивається незалежно від рівня протеїнурії, спостерігається високе вірусне навантаження (РНК ВІЛ >100 000 копій/ мл), зниження абсолютного числа CD4+-лімфроцитів менше 200 клітин/мкл.

4. ВІЛ-асоційована несропатія зустрічається переважно в негроїдній популяції, патогенез ще недостатньо вивчений. Схема лікування не розроблена, у всіх зареєстрованих випадках хворі були чоловіки. 


\section{ОГЛЯДИ ТА ЛЕКЦІї}

5. ВІЛ-асоційована тромботична мікроангіопатія схожа за клінічними проявами до ВІЛ-асоційованої нефрропатії, проте рідко трапляється в популяції негроїдної раси, найчастіше вражає осіб чоловічої статі європейського походження. Тяжко піддається лікуванню, призводить до хронічної ниркової недостатності, а згодом до летального завершення.

6. Імунно-комплексний гломерулонефрит є частим явищем при автопсичному дослідженні нирок у ВІЛінфрікованих, особливо в поєднанні з гепатитом В і С. Ураження ниркової системи виникають на тлі ВААРТ, за наявності інших опортуністичних захворювань.

7. Зважаючи на актуальність ВІЛ-інфекції в наш час, ураження ниркової системи потребує вивчення, а саме функціонального стану, морфологічних та автопсичних змін нирок і дослідження специфічних маркерів.

\section{Література}

1. Кучменко О.Б. Проблеми СНІДу в Україні та методика подолання / О.Б. Кучменко // Проблеми освіти. - 2006. - № 48. - C. 27-31.

2. ВІЛ-інфекція в Україні: Інф. бюлетень № 41. - К.: МОЗ України, Інф. Центр профрілактики і боротьби зі СНІДом, 2014. - 24 с.

3. ВІЛ-інфекція в Україні: Інф. бюлетень № 44. - К.: МОЗ України, Інфр. Центр просрілактики і боротьби зі СНІДом, 2015. - 24 с.

4. Стан імунної системи у хворих на ВІЛ-інфекцію/СНІД під впливом антиретровірусної терапії / [В.Д. Москалюк, В.Д. Сорохан, С.P. Меленко та ін.] // Naukowa przestrzeń Europy. - 2013. - № 29. - С. $87-88$.

5. Ройт А. Иммунология / А. Ройт, Дж. Бростоффф, Д. Мейл: Пер. с англ. - М.: Мир, 2000. - 592 с.

6. Чорнецька В.Д. Деякі медико-біологічні аспекти фрормування у студентів уявлення про небезпеку ВІЛ/СНІД / В.Д. Чорнецька // Проблеми освіти. - 2006. - № 48. - С. 32-37.

7. Заплатинський В.М. Питання профілактики ВІЛ/СНІДу у галузевих стандартах вищої освіти / В.М. Заплатинський, В.Д. Чорненька // БЖД: освіта, наука, практика: Матеріали VI наук.-метод. конср. - К.: НАУ, 2005. - С. 87-92.

8. Кочарян К.А. Клинико-лабораторная характеристика поражений почек у ВИЧ-инфицированных пациентов: авторефр. дис. ... канд. мед. наук / К.А. Кочарян. - М., 2012. - 20 с.

9. Варианты поражения почек при ВИЧ-инфекции / [Н.Д. Ющук, Г.В. Волгина, Ю.В. Мартынов и др.] // Терапевт. архив. - 2008. № 12. - C. 78-81.

10. Predictors of renal outcome in HIV-associated nephropathy / [F.A. Post, L.J. Campbell, L. Hamzah et al.] // Clin. Infect. Dis. - 2008. - Vol. 46. - P. 1282-1289.

11. Первый опыт применения тенофовира при лечении больных ВИЧ-инфекцией в России / [О.Г. Юрин, М.Д. Голиусова, М.О. Деулина и др.] // Эпидемиология и инфекционные болезни. - 2013. - №1. - С. 62-69.

12. Kimmel P.L. The nephropathies of HIV infection: pathogenesis and treatment / P.L. Kimmel // Curr. Opin. Nephrol. Hypertens. - 2000. - Vol. 9. - P. 117-122.

13. Рябоконь О.В. Особливості ураження нирок в умовах високоактивної антиретровірусної терапії у хворих на ВІЛ/СНІД / О.В. Рябоконь, Т.Є. Онищенко, О.Л. Колтунік // Патологія. -2013. - № 2 (28). - C. 85-87.
14. Kimmel P.L. Immune complex glomerulonephritis associated with HIV infection / P.L. Kimmel, J.S. Berns, J.H. Stein. - New York: Churchill Livingstone, 1995. - P. 77-110.

15. Scialla J.J. Relapse of HIV-associated nephropathy after discontinuing highly active antiretroviral therapy / J.J. Scialla, M.G. Atta, D.M. Fine // AIDS. - 2007. - Vol. 21, N 2. - P. 263-264.

16. Горобец О.П. Особенности ВИЧ-ассоциированной нефропатии в зависимости от степени иммунной недостаточности / О.П. Горобец, В.С. Гоженко, А.И. Гойдык // Буковинський медичний вісник - 2012. - Т. 16, № 3 (63), ч. 2. - С. 91-92.

17. Мочевой синдром у ВИЧ-инсрицированных больных в стадии СпИДа / [А.И. Гоженко, О.П. Горобец, В.С. Гойдык и др.] // Несрология. - 2008. - № 12 (4). - С. 54-58.

18. Гоженко А.І. Пієлонесрит у ВІЛ-інфрікованих хворих у стадії СНІДу / А.І. Гоженко, О.П. Горобець, В.С. Гойдик // Дерматовенерология. Косметология. Сексопатология. - 2008. - № 1-2. - C. 233-236.

19. Бартлетт Д. Клинические аспекты ВИЧ-инсекции / Д. Бартлетт, Д. Галлант, П. Фам. - М.: Р. Валент, 2012. - 528 с.

20. Fanconi syndrome and renal failure induced by tenofovir: a first case report / [D. Verhelst, M. Monge, J.L. Meynard et al.] // Am. J. Kidney Dis. - 2002. - Vol. 40. - P. 1331-1333.

21. Гаджикулиева М.М. Хроническая болезнь почек у ВИЧиноицированных пациентов, распространенность и клинико-морфологическая характеристика: автореф. дис. ... докт. мед. наук / М.М. Гаджикулиева.- М., 2013. - 47 с.

22. Andrew M. Tenofovir-associated kidney toxicity in HIV-Infected patients / M. Andrew // Am. J. Kidney Dis. - 2011. - N 57. - P. 773-780.

23. Paul L. Pathogenesis and treatment of HIV-associated renal diseases: lessons from clinical and animal studies, molecular pathologic correlations, and genetic investigations / L. Paul // Ibid. 2003. - N 139. - C 87-100.

24. Sacristian F. Nephrotic syndrome due to thrombotic microangiopathy (TMA) as the first manifestation of human immunodeficiency virus infection: recovery before antiretroviral therapy without specific treatment against TMA / F. Sacristian, S. Alonso // Clin. Nephrol. - 2001. - Vol. 55. - P. 404-407.

25. Бондаренко В.Н. Оценка функции почек у ВИчинорицированных пациентов: креатинин или цистатин С? (обзор литературы) / В.Н. Бондаренко // Проблемы здоровья и экологии - 2012. - № 1. - C. 15-19.

26. Jones C.Y. Cystatin $C$ and creatinine in an HIV cohort: the nutrition for healthy living study / C.Y. Jones // Am. J. Kidney Dis. 2008. - Vol. 51. - P. 914-924.

27. Overton E.T. Factors associated with renal dysfunction within an urban HIV-infected cohort in the era of highly active antiretroviral therapy / E.T. Overton // HIV Med. - 2009. - Vol. 10. - P. 343-350.

28. Esezobor C.I. Kidney function of HIV-infected children in Lagos, Nigeria: using Filler's serum cystatin C-based formula / C.I. Esezobor // J. Int. AIDS Soc. - 2010. - Vol. 13. - P. 17.

29. Jaroszewicz J. Does HAART improve renal function? An association between serum cystatin C concentration, HIV viral load and HAART duration / J. Jaroszewicz // Antivir. Ther. - 2006. - Vol. 11. - P. 641-645.

30. Briggs W.A. Clinicopathologic correlates of prednisone treatment of human immunodeficiency virus-associated nephropathy / W.A. Briggs, S. Tanawattanacharoen, M.J. Choi // Am. J. Kidney Dis. - 1996. - Vol. 28. - P. 618-621.

31. Chidambaram M. Type I membranoproliferative glomerulonephritis in an HIV-infected individual without hepatitis C co-infection / M. Chidambaram, C.E. Stigant, L.M. Sugar // Clin. Nephrol. - 2002. - Vol. 57. - P. 154-157. 


\section{CLINICAL-MORPHOLOGICAL AND FUNCTIONAL CHANGES OF RENAL SYSTEM IN HIV-INFECTED}

V.D. Moskaliuk, M.O. Andrushchak

SUMMARY. It is established that the virus HIV affects the renal system. The data that antiretroviral therapy (HAART) has negative effects on the kidneys and their function. Also found that are morphological and functional changes in the nature of the HIV-infected. In the literature describes few data on drug correction of these changes.

Key words: HIV infection, HIV-associated nephropathy, focal segmental glomerulosclerosis, chronic renal failure, glomerular filtration rate, protein tsystatyn.

Отримано 12.04.2016 р.

() Андрейчин Ю.М., Омеляш В.І., 2016

УДК 616.216-002-07

DOI

\section{Ю.М. Андрейчин, B.I. Омеляш ДІАГНОСТИКА СИНУСИТІВ}

Тернопільський державний медичний університет ім. І.Я. Горбачевського

Зазначено, що актуальність діагностики та лікування запальних процесів у приносових пазухах не зменшується, попри значні досягнення у вивченні цієї патології. У повідомленні здійснено аналіз літератури з таких питань: зовнішній огляд, пальпація, перкусія та аускультація приносових пазух; риноскопія. Наведені дані можуть бути корисними не тільки для оториноларингологів, а й для інших фрахівців: ендоскопістів, рентгенологів, фрізіотерапевтів, лікарів фуункціональної діагностики, сімейних лікарів та ін.

Ключові слова: запалення приносових пазух, синусит, діагностика, риноскопія.

Гострі і хронічні запалення приносових пазух (синусити) спостерігаються досить часто серед дорослого і дитячого населення [1-9]. Біля $15 \%$ населення хворіє на гострі і хронічні синусити, а в 30 \% випадків ця патологія вчасно не діагностується $[2,10]$. Гострі синусити складають у структурі амбулаторної зверненості від 40 до $60 \%$ [6]. Частота гострих і хронічних синуситів постійно зростає на 1,5-2 \% на рік [1]. Актуальність проблеми діагностики та лікування осіб із запальними процесами у приносових пазухах, не дивлячись на значні досягнення у вивченні цієї патології, не зменшується [11, 12]. Про це свідчить велика кількість наукових публікацій [9, 13-26].

При аналізі літератури ми не знайшли оглядових робіт стосовно діагностики синуситів, за винятком двох: в одній з них [27] описуються діагностичні можливості методик термографії в оториноларингології, де певне місце відводиться діагностиці синуситів, і в одній [28] - застосування термограсрії в оториноларингології, в якій також наводяться дані щодо діагностики синуситів. Тому наводимо свій власний огляд літератури з цього питання, який, на нашу думку, може виявитись корисним не тільки для оториноларингологів, а й для інших фахівців (ендоскопістів, рентгенологів, фрізіотерапевтів, лікарів фрункціональної діагностики, сімейних лікарів та ін.). В цьому повідомленні наводиться огляд літератури по наступних питаннях: 1) зовнішній огляд, пальпація, перкусія і аускультація приносових пазух; 2) риноскопія. Що стосується інших методів діагностики синуситів, то вони будуть предметом обговорення в наступних повідомленнях. Перш ніж приступити до викладення матеріалу в даному огляді, вважаємо за необхідне зупинитись на деяких анатомічних і клінічних назвах, наведених в цитованих нами публікаціях. Приносові пазухи описуються під різними назвами: біляносові пазухи [19, 29-31], навколоносові пазухи [4, 32, 33], параназальні пазухи [34], придаткові пазухи носа [35], власне приносові пазухи [36]. Верхньощелепну пазуху описують під назвами: гайморова пазуха і власне верхньощелепна пазуха $[37,38]$. Решітчасту пазуху називають гратчастою пазухою [37], лобову - лобною пазухою [39], основну - клиновидною пазухою [15, 40-43].

Запалення приносових пазух подається під різними назвами: синуїти [5, 14, 17, 36, 44-48], синусити [1-3, 6, 8, 11, 21-23, 33, 49-53], параназальні синуїти [34], запальні процеси біляносових пазух [19], запальні процеси 